\title{
PENERAPAN APLIKASI SLIMS AKASIA DALAM PELAYANAN INFORMASI PEMUSTAKA DI UPT PERPUSTAKAAN UNIVERSITAS MATARAM PERIODE 2019
}

\author{
Ridwan ${ }^{1}$, Supriadin Susanto ${ }^{2}$ \\ Jurusan Ilmu Perpustakaan, Fakultas Ilmu Sosial dan Ilmu Politik \\ Universitas Muhammadiyah Mataram \\ Ridwanr3202gmail.com
}

\section{INFO ARTIKEL}

\section{Riwayat Artikel:}

Diterima:...-...-...

Disetujui:...-...-...

\section{Kata Kunci:}

Slims Akasia,

Pelayanan Informasi, Pemustaka

\begin{abstract}
ABSTRAK
Penelitian ini berjudul Penerapan Aplikasi SLIMS Akasia Dalam Pelayanan Informasi Pemustaka di UPT Perpustakaan UNRAM:1) Untuk Mengetahui bagaimana Penerapan Aplikasi SLIMS Akasia Dalam Pelayanan Informasi Pemustaka di UPT Perpustakaan Universitas Mataram 2) Untuk Mengetahui Kendala-Kendala dalam Penerapan Aplikasi SLIMS Akasia Dalam Pelayanan Informasi Pemustaka di UPT Perpustakaan Universitas Mataram. Metode penelitian yang digunakan adalah Metode penelitian kualitatif dengan pengumpulan data menggunakan observasi, wawancara, dan dokumentasi. Hasil penelitian menujukan bahwa: pertama Aplikasi SLIMS Akasia di UPT perpustakaa unram diterapkan pada pelayanan informasi pemustaka, Kegiatan layanan sirkulasi terdiri dari peminjaman bahan pustaka, pengembalian bahan pustaka, perpanjangan masa pinjam bahan pustaka, pembuatan kartu anggota Perpustakaan, perpanjang masa keanggotaan perpustakaan, penentuan denda, dan sebagainya. Didalam SLIMS Akasia terdiri dari beberapa menu yaitu: OPAC, Bibliografi, Sirkulasi, Keanggotaan. Kedua Cara mengatasi kendala-kendala pada Penerapan SLIMS Akasia dalam pelayanan informasi pemustaka di UPT Perpustakaan unram yaitu: 1). menprogramkan untuk pengadaan genset sebagai langkah antisipasi bila terjadi mati lampu,2) Mengadakan worshop dan pelatihan untuk meningkatkan kualitas, keterampilan(Skill) pustakawan agar lebih handal.
\end{abstract}

\section{A. PENDAHULUAN}

Perpustakaan Perguruan Tinggi merupakan perpustakaan yang terdapat pada lembaga perguruan tinggi, badan bawahannya maupun lembagan yang berafiliasi dengan perguruan tinggi, dengan tujuan utama membatu perguruan tinggi mencapai tujuannya (Sulistyo Basuki, 2010:2-17).

Tujuan umum penyelenggaraan perpustakaan adalah turut memperlancar dan menyukseskan fungsi penguruan tinggi yang bersangkutan yaitu dharma perguruan tinggi (pendidikan, penelitian, pengabdian pada masyarakat). Sesuai dengan surat keputusan menteri pendidikan dan kebudayaan No.0103/o/1981, perpustakaan perguruan tinggi berfungsi sebagai pusat kegiatan belajar-mengajar, pusat penelitian dan informasi bagi pelaksanaan tri dharma perguruan tinggi.

Secara umum tugas perpustakaan penguruan tinggi adalah menyusun kebijakan dan melakukan tugas rutin untuk mengelolah dan merawat bahan pustaka serta mendayagunakannya baik bagi civitas akademika maupu masyarakat di luar kampus.

Penerapan teknologi informasi di Perpustakaandibutuhkan agar informasi dapat diperoleh dengan lebih cepatdan mudah. Oleh karena itu, perpustakaan membutuhkan penerapan teknologi informasi untuk meningkatkan kualitas layanan informasi pemustaka agar lebih efektif dan efisien.

UPT Perpustakaan Universitas Mataram merupakan salah satu perpustakaan penguruan tinggi yang memliki peranan penting dalam memberikan informasi dan pelayanan yang baik 
kepada mahasiswa,dosen, karyawan dan civitas akademika.

\section{Senayan Library Management System} (SLIMS) merupakan salah satu kompenen penting dalam implementasikan automasi perpustakaan yang dapat melakukan kegiatan pelayanan perpustakaan seperti penelusuran online public access catalog (OPAC), layanan sirkulasi, manajemen keanggotaan, dan Visitor Control. Aplikasi Senayan Library Management System (SLIMS) dengan versi SLIMS 8.2 Akasia, Tujuannya untuk meningkatkan layanan yang lebih prima. Adapun keunggulan yang dirasakan setelah SLIMS diterapkan, diantaranya dilihat dari segi efesiesi waktu, Dalam penelusuran informasi waktu yang dibutuhkan lebih sedikit dan hasil yang lebih akurat, dan dapat meningkatkan proses peminjaman dan pengembalian buku di bagian sirkulasi lebih mudah dan lebih cepat kerjanya.

Dari hasil wawancara peneliti terhadap salah satu staf perpustakaan dari universitas mataram kendala tersebut antara lain listrik yang sering mati sehingga kerja sistem, keterampilan dan pemahaman pustakawan masih perlu ditingkatkan, penelusuran informasi pada layanan OPAC seringkali mengalami gangguansehingga hasil penelusuran menjadi kurang akurat.Secara otomatis sangat mempengaruhi pada kualitas layanan yang diberikan kepada pemustaka.

Dengan adanya penerapan aplikasi SLIMS akasia dapat meningkatkan pelayanan yang efektif dan efisien bagi pemustaka. karenakan maksimal dalam meningkatkan produktifitas dalam penerapan aplikasi SLIMS akasia.

Dari uraian di atas penulis tertarik untuk mengkaji lebih mendalam tentang bagaimana "Penerapan Aplikasi Senayan Library Management System (SLIMS) Akasia Dalam Pelayanan Informasi Pemustaka di UPT Perpustakaan Universitas Mataram”.

\section{B. RUMUSAN MASALAH}

Berdasarkan uraian dari latar belakang diatas maka penulis melakukan serangkaian analasis serta observasi dengan permasalahan sebagai tersebut:

1. Bagaimanakah Penerapan Aplikasi Senayan Library Management System (SLIMS) Akasia Dalam Pelayanan Informasi Pemustaka di UPT Perpustakaan Universitas Mataram ?

2. Kendala apa saja dalam Penerapan Aplikasi Senayan Library Management System (SLIMS) Akasia Dalam Pelayanan Informasi Pemustaka di UPT Perpustakaan Universitas Mataram?

\section{LANDASAN TEORI}

Perpustakaan merupakan sebuah ruangan ataupun gedung yang dimana terdapat berbagai jenis koleksi bahan pustaka seperti buku, koran, majalah, jurnal dan masih banyak lagi bahan pustaka yang diorganisasikan sebagai sumber belajar atau sebagai referensi buat seseorang atau sekelompok orang yang memanfaatkan perpustakaan.

Adapun beberapa definisi tentang perpustakaan menurut para ahli yaitu sebagai berikut:

1. Perpustakaan adalah sebuah ruangan, bagian sebuah gedung. Ataupun gedung itu sendiri yang di gunakan untuk menyimpan buku dan terbitan lainnya yang biasanya di simpan menurut tatasusunan tertentu untuk digunakan pembaca, bukan untuk dijual (Sulistiyo-Basuki,1993:3).

2. Perpustakaan adalah kumpulan atau gabungan fisik sebagai tempat buku di kumpulkan dan disusun menurut system tertentu atau keperluan pemustaka (Lasa,2007:12).

3. Perpustakaan adalah mencakup suatu ruangan, bagian dari gedung/ bangunan atau gedung tersendiri yang berisi buku-buku koleksi, yang diatur dan disusun sedemikian rupa, sehingga mudah untuk dicari dan dipergunakan apabila sewaktu-waktu diperlukan oleh pembaca (Sutarno NS, 2006:11). 
4. Perpustakaan merupakan unit kerja yang didalamnya ada organisasi, sebab tampa organisasi perpustakaan ini tidak beda dengan individu lainnya. Artinya perpustakaan merupakan kegiatan yang melibatkan lebih dari satu individu dan saling bekerjasama. Dengan kata lain perpustakaan dapat jugadiartikansebagaikumpulaninformasi yang bersifatilmupengetahuan, hiburan, rekreasidanibadah yang merupakankebutuhanhakikimanusia, (WijiSuwarrno, 2001: 13).

5. Perpustakan adalah institusi pengelola koleksi karya tulis, karya cetak, dan karya rekam secara propesional dengan sistem yang baku guna memenuhi kebutuhan pendidikan, penelitian, pelestarian, informasi, dan rekreasi bagi para pemustaka (UU No. 43 Tahun 2007 Pasal 1 Ayat

Dari beberapa teori diatas penulis dapat menyimpulkan bahwa Perpustakaan merupakan suatu unit kerja yang didalamnya terdapat buku atau koleksi yang tercetak maupun noncetak yang disusun secara sistematis menurut tatasusunan tertentu untuk memenuhi kebutuhan pemustaka. Perpustakaan tidak hanya dianggap sebagai sebuah gedung tempat menyimpanan buku tetapi keberadaan perpustakan menjadi sangat penting karena kebutuhan masyarakat yang tinggi akan informasi yang dapat menunjang segala aktivitas pendidikan, penelitian dan perkembangan kebudayaan, ekonomi dan sosial.

\section{Perpustakaan Perguruan Tinggi}

\section{a. Pengertian Perpustakaan Perguruan Tinggi}

Pada dasarnya semua perpustakaan merupakan suatu instansi yang memiliki proses kerjasama, yaitu memberikan pelayanan informasi kepada pemustaka. Namun demikian dalam perkembangannya setiap jenis perpustakaan memiliki definisi dan kriteria tertentu yang membedakannya dengan perpustakaan lain. Perpustakaan perguruan tinggi merupakan salah satu jenis dari sekian banyak jenis perpustakaan yang telah dikategorikan.

Perpustakaan perguruan tinggi adalah perpustakaan yang berada dalam suatu perguruan tinggi dan merupakan unit yang menunjang perguruan tinggi yang bersangkutan dalam mencapai tujuannya. Yang termasuk dalam pengertian perpustakaan perguruan tinggi adalah perpustakaan yang tergabung dalam lingkungan lembaga pendidikan tinggi baik perpustakaan Universitas, fakultas, institute, sekolah tinggi maupun politeknik.

Menurut Noerhayati (1987:1) Perpustakaan perguruan tinggi adalah suatu unit kerja yang merupakan bagian integral dari suatu lembaga induknya yang bersama-sama unit lainnya tetapi dalam peranan yang berbeda, bertugas membantu perguruan tinggi yang bersangkutan melaksanakan Tri Dharmanya.

Sejalan dengan pernyataan diatas perpustakan perguruan tinggi merupakan suatu unit pelaksana teknis UPT perpustakaan perguruan tinggi yang bersama-sama unit lain turut melaksankan Tri Dharma perguruan tinggi dengan cara memilih, menghimpun, mengolah, merawat, dan melayankan sumber informasi kepada lembaga induknya pada khususnya dan masyarakat akademisi pada umumnya (Syihabuddin Qalyubi, 2007:10).

Dari beberapa pendapat diatas, dapat disimpulkan bahwa perpustakaan perguruan tinggi adalah perpustakaan yang terdapat pada perguruan tinggi yang berfunggi menyediakan dan menyebar informasi guna membantu perguruan tinggi untuk mencapai tujuannya yakni Tri Dharma Perguruan Tinggi seperti, 
pendididkan, penelitian, dan pengabdian masyarakat.

\section{b. Tujuan Perpustakaan Perguruan Tinggi}

Tujuan perpustakaan perguruan tinggi harus sejalan dengan perguruan tingginya. Sebagai unsur penunjang perguruan tinggi dalam mencapai visi dan misinya.

Menurut Suliatyo Basuki (1993:218), tujuan perpustakaan perguruan tinggi adalah sebagai berikut:

1) Memenuhi keperluan informasi masyarakat perguruan tinggi, lazimnya staf pengajar dan mahasiswa. Sering pula mencakup tenaga administrasi perguruan tinggi.

2) Menyediakan materi perpustakaan rujukan (Referensi) pada semua tingkat akademis, artinya mulai dari mahasiswa tahun pertama hingga kemahasiswa program pasca sarjana dan pengajar.

3) Menyediakan ruangan belajar untuk memakai perpustakaan.

4) Menyediakan jasa peminjaman yang tepat guna bagi berbagai jenis pemustaka.

5) Menyediakan jasa informasi aktif yang tidak terbatas pada lingkungan perguruan tinggi tetapi juga lembaga industry lokal.

Menurut Syihabuddin Qalyubi (2007:11), tujuan perpustakaan perguruan tinggi yaitu untuk: (1) memenuhi kebutuhan informasi pelajar dan mahasiswa, (2) menyediakan bahan pustaka rujukan pada semua tingkat akademis, (3) menyediakan ruangan untuk pemustaka, (4) menyediakan jasa peminjaman dan menyediakan jasa informasi aktif bagi pemustaka.

Berdasarkan beberapa pendapat diatas, dapat disimpulakan bahwa tujuan perpustakaan perguruan tinggi adalah untuk mendukung kinerja dari perguruan tinggi dalam menyelenggarakan pendidikan dengan menyediakan sumber-sumber informasi ilmiah bagi masyarakat perguruan tinggi tersebut agar pelaksanaan program kegiatan perguruan tinggi berjalan denganlancar dan berkualitas.

\section{Fungsi Perpustakaan Perguruan Tinggi}

Pada umumnya, perpustakaan perguruan tinggi memiliki beberapa fungsi sebagai berikut, (Wijayanti Et Al, 2004).

a. Fungsi edukasi: Perpustakaan merupakan sumber belajar bagi para anggota civitas akademikanya. Oleh karena itu, koleksi yang tersedia adalah koleksi yang mendukung kegiatan belajar-mengajar di perguruan tinggi.

b. Fungsi informasi: Perpustakaan merupakan sumber informasi yang mudah diakses oleh para pencari dan seseorang yang memanfaatkan informasi.

c. Fungsi riset: Perpustakaan menyediakan bahan-bahan pustaka mutahir yang mendukung pelaksanaan penelitian ilmu, teknologi, dan seni.

d. Fungsi rekreasi: Perpustakaan menyediakan koleksi yang dapat membantu untuk mengembangkan minat, kreatifitas, dan daya inovatif para pemustaka.

e. Fungsi deposit: Perpustakaan menjadi pusat penyimpanan karya ilmiah yang dihasilkan oleh para anggota civitas akademikanya.

\section{Pengertian Pustakawan}

Kata pustakawanberasaldari kata “pustaka”.Penambahan kata "wan" diberikan sebagai orang yang pekerjaannya atau profesinya berkaitan erat dengan dunia pustaka atau bahan pustaka. Dalam Bahasa Inggris pustakawan disebut sebagai "librarian" 
yang juga terkait dengan kata "library".Dalam perkembangan selanjutnya, istilah pustakawan diperkayalagi dengan istilah-istilah lain, meskipun hakikat pekerjaannya sama, yaitu sama-sama mengelola informasi, diantaranya pakar informasi, pakar dokumentasi, pialang informasi, manajer pengetahuan, dan sebagainya.

Secara tradisional definisi pustakawan adalah orang yang ahli dalam mengelola koleksi buku dan bahan-bahan informasi lainnya; dan membantu pemustaka untuk mengakses koleksi tersebut ( Feather \& Sturges,1997:252).

Sedangkan Harrod mendefinisikan pustakawan sebagai orang yang mengelola perpustakaan dan isinya, menyeleksi bukubuku, dokumen dan bahan non buku untuk memenuhi kebutuhan pemustakanya ( Harrod, 1987:451).

Namun saat ini, pustakawan adalah manajer dan mediator dalam mengakses informasi untuk pemustakayang berasal dari berbagai bidang. Pustakawan tidak hanya mengakses melalui koleksi dan bahan-bahan informasi yang tersedia di perpustakaan tetapi juga melalui sumber-sumber informasi yang tersedia diluar perpustakaan yang dapat diakses secara global (Feather \& Sturges,1997:253).

Pustakwan atau librarian adalah seorang tenaga kerja bidang perpustakaan yang telah memiliki pendidikan ilmu perpustakaan, baik melalui pelatihan, kursus, seminar, maupun dengan kegiatan sekolah formal.Pustawan ini orang yang bertanggung jawab terhadap gerak maju roda perpustakaan.Maka, di wilayah Pegawai Negeri Sipil (PNS), pustakawan masuk kedalam jabatan fungsional. Secara umum, kata Pustakwan merujuk pada kelompok atau perorangan dengan karya atau profesi dibidang dokumentasi, informasi, dan perpustakaan (Sudarsono, 2006:78).

Dalam Undang-Undang Republik Indonesia Nomor 43 Tahun 2007, pasal 1, menyebutkan bahwan Pustakawan adalah seseorang yang memiliki kompetensi yang diperolehnya melalui pendidikan dan / atau pelatihan kepustakawanan serta mempunyai tugas dan tanggung jawab untuk melaksanakan pengelolaan dan pelayanan perpustakaan.

Dari uraian diatas dapat disimpulkan bahwa pustakawa adalah seseorang yang bekerja dipepustakaan sebagai pengelola koleksi buku, bahan informasi, dan yang telah menepuh pendidikan dibidang ilmu perpustakaan, baik pelatihan, kursus, seminar, maupun kegiatan perpustakaan lainya. Perpustakaan juga sebagai orang yang bertanggung jawab terhadap kemajuan perpustakaan yang dikelolanya.

\section{Peran Pustakawan}

Pada umumnya orang berpendapat bahwa peran pustakawan hanya sebagai pegawai yang kerjaannya hanya menjanga perpustakaan dan koleksi yang ada dilamnya. Namun peran pustakawan tidak hanya menjanga buku akan tetapi sudah saatnya mengekspresikan diri sebagai media informasi yang berkualitas.

Sebagaimana diataur dalam Menpan No.132/Kep/M.Pan/12/2002, pustakawan memang sangat diperlukan di perpustakaan perguruan tinggi. Peran utama pustakawan yang dimaksudkan adalah sebagi pengorganisai bahan pustaka untuk memenuhi kebutuhan pemustaka dan sebagai pembimbing tentang cara-cara bagaimana menggunakan bahan pustaka untuk kempentingan pemustaka sehingga dapat dimanfaatkan secara optimal. Dengan kata lain keberadaan pustakawan di perpustakaan perguruan tinggi diperlukan untuk 
mendayagunakan bahan pustaka yang dimiliki secara maksimal, sehingga bahan pustaka tidak hanya disempan, tetapi harus diatur dan diorganisasikan sesuai dengan tujuan dan fungsi perpustakaan.

MenurutHermawan Rachman (2006:57) peranan pustakawan dalam melayani pemustakanya dan sangat beragam, misalnya pada perpustakaan disamping menjadi pustakawan dapat pula sebagai peneliti, minimal sebagai mitra peneliti.

Dalam banyak hal pustakawan memainkan berbagai peran sebagai berikut:

1) Edukator

Sebagai edukator (pendidik), pustakawan dalam melaksanakan tugasnya harus berfungsi dan berjiwa sebagai pendidik. Mendidik adalah mengembangkan kepribadian, mengajar adalah mengembangkan kemampuan berpikir dan melatih adalah membina dan mengembangkan keterampilan. Oleh karena itu, pustakawan harus memiliki kecakapan mengajar, melatih mengembangkan, baik para pegawai maupun para pemustaka jasa yang dilayaninya.

2) Manajer

Pada hakikatnya pustakawan adalah "manajer informasi" yang mengelola informasi pada satu sisi, dengan seseorang yang memanfaatkan informasi pada sisi lain. Informasi yang banyak dan terdapat dalam berbagai wadah yang jumlah selalu bertambah harus dikelola dengan baik.

3) Administrator

Sebagai administrator pustakawan harus mampu menyusun, melaksanakan dan dicapai, kemudian upaya-upaya perbaikan untuk mencapai hasil yang lebih mengevaluasi program perpustakaan, serta dapat melakukan analisis atas hasil yang telah baik. Oleh karena itu, seorang pustakawan harus mempunyai pengetahuan yang luas dibidang oraganisasi, sistem dan prosedur kerja.

Dari uraian diatas maka peranan pustakawan sangat penting, karena mereka dapat mengatur alokasi sumber daya bagi perkembangan memenuhi seluruh sarana prasarana dan perlengkapan yang diperlukan dan merekalah sebagai penentu yang dapat mengantisipasi berbagai gambaran dan imajinasi untuk perkembangan perpustakaan yang akan dicapai dimasa mendatang.

\section{Kinerja pustakawan}

Pustakawan adalah orang yang pekerjaannya atau profesinya terkait erat dengan dunia pustaka atau bahan pustaka. Menurut Ikatan Pustakawan Indonesia (IPI), Pustakawan adalah seseorang yang melaksanakan kegiatan perpustakaan dengan jalan memberikan pelayanan kepada masyarakat sesuai dengan tugas lembaga induknya berdasarkan ilmu pengetahuan, dokumentasi dan informasi yang dimilikinya melalui pendidikan.

Menurut Rachman dan Zen (2006:19-20) Pustakwan dikelompokan menjadi tiga yaitu:

1) Pustakawan ahli adalah mereka yang memeliki kualifikasi ahli dengan latar belakang pendidikan ilmu perpustakaan minimal serjana atau berpengalaman lama mengelola perpustakaan secara profesional .

2) Pustakawan terampil adalah yang menguasai teori-teori perpustakaan daterampil memanfaatkan dalam melaksanakan tugastugas rutin perpustakaan seperti pengadaan, pengelolahan dan pelayanan.

3) Pustakawan penunjang adalah pustakawan yang banyak melakukan pekerjaan-pekerjaan administratif atau pekerjaan yang sifatnya umum dan tidak terkait dengan ilmu perpustakan dan informasi. 
Adapun konsep kinerja Menurut Wirawan (2009:5) adalah keluaran yang dihasilkan oleh fungsi-fungsi atau indikatorindikator suatu pekerjaan suatu pekerjaan atau suatu profesi dalam waktu tertentu. Pekerjaan adalah aktifitas menyelesaikn sesuatu yang hanya memerlukan tenaga dan ketrampilan tertentu seperti yang dilakukan oleh pekerja kasar atau bleu collar worker. Sementara itu profesi adalah pekerjaan yang untuk menyelesaikannya memerlukan penguasaan dan penerapan teori ilmu pengetahuan yang dipelajari dari lembaga pendidikan tinggi seperti yang dilakukan oleh profesional atau white collar worker.

Menurut Wirawan (2009:54)dimensi kenerja dapat dikelompokan menjadi 3 jenis dan sifat pribadi yang berhubungan dengan pekerjaan.

1. Hasil kerja

Hasil kerja keluaran kerja dalam bentuk barang dan jasa yang dapat di hitung dan diukur kauntitas dan kualitasnya.

2. Perilaku kerja

Ketika berada di tempat kerjanya, seorang karyawan mempunyai dua perilaku yaitu pribadi dan perilaku kerja.

3. Sifat pribadi yang ada hubungan dengan pekerjaan.

Ialah sifat pribadi karyawan yang diperlukan dalam melaksanakan perkerjaannya.

Dalam konsep manajemen perpustakaan, pustakawan adalah sebagai sumber daya dalam perpustakaan diharapakan mampu untuk memanfaatkan perpustakaan danmeningkatkan tenaga sepenuhnya atau seoptimal mungkin untuk meningkatkan produktifitas yang diikuti oleh terciptanya hubungan kerja yang bermutu dengan konotasi yang menyenangkan, penuh tenggang rasa dan saling membangun. Produktifitas meningkat salah satunya adalah kinerja pustawanan yang maksimal.

Kinerja pustakawan merupakan hasil atau tingkat keberhasilan seorang secara keseluruhan untuk menyelesaikan tugas atau pekerjaan dengan derajat kesediaan dan tingkat kemampuan tertentu dengan pemahaman yang jelas tentang apa yang akan dikerjakan dan bagaimana mengerjakannya selama periode tertentu di dalam melaksanakan tugas dibadingkan dengan berbagai kemungkinan seperti standar hasil kerja, target atau sasaran atau kriteria yang telah ditentukan terlebih dahulu dan telah disapakati bersama Lubis, (2008).

Produktifitas tenaga kerja (kinerja pustakawan) adalah perbandingan antara hasil yang di capai dengan peran serta tenaga kerja persatuan waktu, sedangkan peran serta tenaga kerja ialah penggunaan sumber daya secara efisiensi dan efektif.

Sedangkan Menurut Mangkunegara (2005) dalam Lubis (2008:40), kinerja pustakawan dipengaruhi oleh 3 faktor yaitu:

1. Faktor individu yang terdiri dari kemampuan dan keahlian, latar belakang dan demografi.

2. Faktor psikologi yang terdiri dari persepsi, sikap, kepribadian, pembelajaran, dan motivasi.

3. Faktor organisasi yang terdiri dari sumber daya, kepemimpinan, penghargaan, struktur, dan job design. Berdasarkan teori di atas dapat di simpulkan bahwa kinerja pustakawan adalah keberhasilan 
seseorang secara keseluruhan untuk menyelesaikan tugas atau pekerjaan menyangkut kualitas, kuantitas, kemampuan kerjasama, kemampuan pemahaman terhadap tugas, kedisiplinan, keinginan melaksanakan tugas baru dan kemampuan peningkatan diri, tetapi juga sangat dipengaruhi oleh semangat kerja.

\section{Senayan Library Management System} (Slims)

\section{a. Pengertian SLiMS}

Dalam sebuah artikel dari Senayan Developer Community tentang "Modul Pelatihan Dasar Pengolahan Perpustakaan Berbasis SLiMS", menyatakan bahwa Senayan Library Management System atau disingkat dengan SLiMS merupakan salah satu free open source software (FOSS) berbasis web yang dapat digunakan untuk membangun sistem dalam penerapan sistem otomasi perpustakaan. Sebagai perangkat lunak, SLiMS mampu berjalan sempurna di dalam sistem jaringan lokal.

b. Tujuan dan Manfaat Penggunaan SLiMS.

Menurut Anonimaus (2012) yang dikutip Tekka Bancin (2014:14), dengan menggunakan sistem automasi Senayan, maka pekerjaan yang ada Sumber Informasi Pengolahan perpustakaan di perpustakaan akan semakin mudah. Manfaat lain dari seseorang yang memanfaatkanSenayan di Perpustakaan, antara lain: (1) Dapat mempercepat proses temu balik informasi (Information Retrieval), (2) Memperlancar proses pengolahan, pengadaan bahan pustaka, dan komunikasi antar perpustakaan, (3) Memudahkan pengolahan data perpustakaan, (4) Meningkatkan citra perpustakaan”.

\section{c. Penerapan Teori Technology Acceptance Model (TAM)}

Sistem informasi dalam suatu instansi, berfungsi sebagai alat bantu pencapaian tujuan melalui penyediaan informasi. Salah satu unsur penting dalam penerapan sebuah sistem informasi adalah penerimaan terhadap sistem informasi tersebut. Bagi sebuah organisasi, sistem informasi berfungsi sebagai alat bantu untuk pencapaian tujuan organisasi melalui penyediaan informasi. Teori Technology Acceptance Model(TAM) bertujuan untuk menjelaskan dan memperkirakan penerimaan (acceptance pemustaka terhadap suatu sistem informasi. Maka ada 2 (dua) faktor yang mempengaruhinya, yaitu :

1. Persepsi Kemudahan Penggunaan (Ease of Use Perceived) Kemudahan (ease) bermakna tanpa kesulitan atau terbebaskan dari kesulitan atau tidak perlu berusaha keras. Hasil yang didapati bahwa penerapan SLiMS padaUPT Perpustakaan Universitas Mataram, sangat memberikan kemudahan bagi pemustaka yang sering ke perpustakaan dalam mengoperasikan SLiMS tersebut dan bagi pemustaka pemula tentunya merasa sulit. Namun terkadang masih mengalami hambatan dalam menggunakan SLiMS, Faktor utama yang menyebabkan yaitu jaringan yang digunakan dalam menerapkan SLiMS, dimana jaringan merupakan komponen penting dalam kelancaran dari SLiMS itu sendiri, jaringan yang kurang baik dapat menganggu kerja dari SLiMS itu sendiri, sehingga menyebabkan tidak meningkatnya minat pemustakadalam menggunakan 
SLiMS, faktor lainnya juga yang terjadi yaitu pemustaka belum terbiasa dalam mengoperasikan atau menggunakan SLiMS itu sendiri.

2. Persepsi Kebermanfaatan(Usefulness Perceived)

Hasil yang diperoleh di lihat Dari segi persepsi kebermanfaatan (Usefulness Perceived) Penerapan SLiMS di UPT Perpustakaan Universitas Mataram, Penerapan SLiMS belum optimal dalam meningkatkan produktivitas karena masih ada kendala yang muncul antara lain kurangnya jumlah unit komputer yang ada di perpustakaan, ketidak sesuaian jumlah unit komputer dengan jumlah pemustaka yang memanfaatkan perpustakaan yang ada, padahal komputer merupakan komponen yang utama dalam mengoperasikan SLiMS itu sendiri, dan juga jaringan masih kurang memadai sehingga lebih membuat kebermanfaatan SliMS belum bisa optimal dirasakan oleh seseorang yang memanfaatkan perpustakaan. Terlebih khusus bagi pemustaka pemula belum merasakan manfaatnya karena belum terbiasa menggunakan SLiMS, dan kurangnya pengetahuan apa sebenarnya manfaat dari SLIMS.

\section{E. HASIL DAN PEMBAHASAN}

\section{Profil UPT Perpustakaan UMMAT}

Sejarah UPT Perpustakaan adalah bersamaan dengan beridirnya Universitas Mataram (Unram) merupakan perguruan tinggi yang diselenggarakan di bawah Kementerian Pendidikan dan Kebudayaan, berkedudukan di Kota Mataram,Provinsi Nusa Tenggara Barat. Proses berdirinya Unram diawali dengan pembentukan Panitia Persiapan Pendirian Universitas Negeri di Mataram berdasarkan Surat Keputusan Menteri PTIP nomor 89/62 tanggal 26 Juni 1962. Panitia ini diketuai oleh Gubernur Kepala Daerah Tingkat I NTB, yaitu: R.Ar.Moh.Ruslan Tjakraningrat. Panitia persiapan ini kemudian membentuk Badan Persiapan, yang terdiri atas dua bagian, yaitu Bagian Inti (Gubernur, Danrem, Kepala Polisi, dan Kepala Cabang Kejati) dan Bagian Penyelenggara (Seksi Pelajaran diketuai oleh Drs. Soeroso, MA dan Seksi Material diketuai oleh Sadili Sastrawidjaja, SH). Sejalan dengan berdirinya Universitas Mataram maka untuk menyelenggrakan roda perpustakaan, UPT perpustakaan di pimpin oleh kepala, mulai dari awal pendirian sampai sekarang ini yang terdiri dari :

1. David Nakan

2. Badimah, BSc

3. I Gusti Bagus Ngurah Hari

4. Drs. Lalu Budiman, SIP

5. Muslimin, S.Sos., MM. tahun 2014-sekarang

Sejak berdirinya perpustakaan Univeritas Mataram pergantian pimpian sebanyak 5 (lima) kali.

\section{Perkembangan UPT Perpustakaan}

Dari 5 (lima) kali pergantian pimpinan kepala perpustakaan, perubahan yang menonjol adalah dengan dibangun gedung perpustakaan yang berlantai 3, pada tahun 2004-2006 perpustakaan memperoleh hibah TPSDP sehingga sampai dengan tahun sedikit ada perubahan pada sistem pelayanan dari manual ke elektronik yang dilengkapi dengan seperangkat sarana dan prasarana. Oleh karena tidak adanya pemeliharaan yang rutin, sarana dan prasarana tersebut sampai saat ini semakin menyusut dan banyak yang tidak berfungsi lagi.

Selanjutnya pada tahun 2013, seiring dengan perubahan paradigma dan kebutuhan informasi di perpustakaan mulai adanya sistem jaringan internet dengan ketersediaan perangkat yang menunjang untuk mengakses informasi yang mengakibatkan 
perubahan penataan ruangan perpustakaan menjadi bertambah yaitu ada ruangan internet dan ruangan multimedia.

Progres pengembangan UPT Perpustakaan Universitas Mataram terus di pacu agar layanan Kepada civitas akademika menjadi lebih maksimal, tentu disadari sepenuhnya bahwa eksistensi perpustakaan universitas Mataram semata mata untuk memberikan layanan informasi ilmiah kepada segenap civitas akademika, serta sebagai salah satu tiang penyanggah kokohnya system pendidikan dan akademik tingkat Universitas Mataram.

Sehingga pada tahun 2014 dimulai sebuah babak baru penataan dan pengembangan perpustakaan hampir disesua lini mendapatkan perhatian yang proporsional, dimulai dari desain interior lobby, ruang layanan sirkulasi, penataan ruang multimedia, peluncuran Café Internet bagi mahasiswa, pembuatan study corner, penataan taman depan perpustakaan dengan menempatkan 2 unit berugak sebagai salah satu kiat untuk mewujudkan kenyamanan bagi pemustaka agar lebih betah berada di perpustakaan. Hal yang tidak kalah kalah penting adalah melakukan penataan system, kebetulan saat ini masih menggunakan SIPISIS versi windows, pelan namun pasti upt perpustakaan universitas mataram mulai beralih ke INLIS LITE, sebagai buah dari kerjasama dengan perpustakan nasional. Sampai disitu pihak perpustakaan belum berhenti berinovasi, masih banyak agenda kedepan yang akan dilakukan dengan melakukan berbagai terobosan dan inovasi seperti :

1.Desain Aplikasi Sistem Repository UNRAM sebagai Local Branding

2. Workshop, pelatihan dan seminar berbasis IT sebagai antisipasi digital Library

3. Membangun jejaring kerjasama pada skop local dan nasional

4. Users, seducation, promosi dan sosialisasi secara kontinyu dengan menyasar semua komponen civitas akademika Universitas Mataram.

UPT Perpustakaan Selalu berusaha menjalankan perpustakaan sebagaimana Dengan fungsi utama perpustakaan adalah menjalankan program Tri darma Perguruan Tinggi di Bidang Pengumpulan Informasi, Pengolahan Informasi, penyimpanan Informasi dan Penyebaran Informasi kepeda segenap Civitas Akademika. Tentunya dengan berpedoman kepada fungsi utama perpustakaan yaitu:

1. Sebagai pusat pendidikan

2. Sebagai pusat sumber informasi

3. Sebagai pusat sumber rujukan penelitian

4. Sebagi pusat penyimpan informasi (information Storage )

5. Sebagi pusat rekreasi dan hiburan

Dengan berpijak pada fungsi tersebut UPT. Perpustakaan Unram mencoba memainkan peran sebagai penunjang proses kegiatan belajar mengajar di perguruan tinggi serta sebagai pusat sumber rujukan bagi para peneliti.

Dengan Demikian UPT. Perpustakaan Universitas Mataram senantiasa terus berusaha melakukan transformasi diri dengan memberdayakan setiap potensi internal organisasi untuk dapat memberikan layanan maksimal kepada segenap civitas akademika.Hingga saat ini UPT. Perpustakaan Universitas Mataram berjalan cukup dinamis sesuai dengan perkembangan inmu pengetahuan dan teknologi. Sebagai perpustakaan perguruan tinggi UPT. Perpustakaan senantiasa terus berusaha melakukan berbagai langkah terobosan untuk tetap terjaganya serta tercapainya peningkatan kualitas layanan informasi kepada segenap civitas akademika. Sehingga UPT. Perpustakaan bisa meraih predikat akreditasi “ B “ yang ditetapkan oleh Perpustakaan Nasional Indonesia pada tanggal 10 November 2012. (Disahkan oleh: Dra. Hj. Sri Sularsih. M.Si ).

Sebagai praktisi dan pegiat perpustakaan tentu kita sangat bersyukur dengan capaian 
tersebut, namun kami tidak berpuas diri hanya sampai disitu. Akan tetapi kami bertekad untuk terus berjuang, berusaha, berkinerja maksimal dengan menggerakkan segenap potensi, sumberdaya dan kemampuan yang ada sehingga harapan kedepan UPT. Perpustakaan Universitas mataram dapat meraih predikat Akreditasi " A “. Memang tidak mudah untuk mencapainya, butuh usaha dan kerja keraas yang sungguh- sungguh, komitmet kelembagaan dan komitment organisasional harus senantiasa terpatri dalam hati dan jiwa para pustakawan, berjalan seiring untuk membesarkan lembaga menjadi lebih baik lagi.Untuk mencapai hal tersebut perlu dipersiapkan berbagai komponen yang saling mendukung satu sama lain seperti :

a. Penyiapan sarana dan prasarana yang memadai

b. Tersedia akses informasi berbasis IT / Internet / Wifi

c. Tersedianya SDM yang kompeten dan handal

d. Tersedianya koleksi perpustakaan yang uptodate

e. Tersedianya layanan penelusuran berbasis EJournal

f. Tersedianya taman yang menarik diseputar perpustakaan untuk suasana belajar santai dengan nuansa rekreasi ilmiah.

g. Tersedianya data base digital berbasis Local Content ( DTS )

Apalagi dengan banyaknya penyedia layanan informasi berbasis jaringan internet diluar perpustakaan, sehingga ini menjadi tantangan tersendiri bagi perpustakaan untuk terus melakukan transformasi diri secara terus menerus.

Hingga saat ini perpustakaan sudah memiliki beberapa fasilitas yang sangat mendukung upaya peningkatan kualitas layanan kepada pemustaka seperti telah tersedianya ruangan multimedia, adanya ruang internet dan gratis bagi mahasiswa, serta fasilitas hotspot gratis untuk mahasiswa. Secara sadar bahwa itu telah menjadi magnet dan kekuatan tersendiri bagi perpustakaan untuk tetap survive dalam pusaran globalisasi informasi. Namun ada bebarapa sisi yang mesih perlu mendapat perhatian lebih guna lebih menggairahkan semangat dan animo mahasiswa serta civitas akademika yang lain untuk senantiasa memanfaatkan perpustakaan.

\section{Dasar Hukum UPT Perpustakaan Mataram.}

1. Undang-Undang Republik Indonesia Nomor 28 Tahun 1999 Tentang Penyelenggaraan Negara Yang Bersih dan Bebas dari Korupsi, Kolusi dan Nepotisme;

2. Undang-undang Republik Indonesia Nomor 17 Tahun 2003 Tentang Keuangan Negara;

3. Undang-Undang Republik Indonesia Nomor 25 Tahun 2005 Tentang Sistem Perencanaan Pembangunan Nasional;

4. Peraturan Pemerintah Nomor 8 Tahun 2006 Tentang Pelaporan Keuangan dan Kinerja Instansi Pemerintah;

5. Instruksi Presiden Nomor 7 Tahun 1999 Tentang Laporan Kinerja Akuntabilitas Kinerja Instansi Pemerintah;

6. Instruksi Presiden Nomor 5 Tahun 2004 Tentang Percepatan Pemberantasan Korupsi;

7. Peraturan Menteri Pendidikan RI No. 14 Tahun 2006 Tentang Laporan Akuntabilitas Kinerja Instansi Pemerintah.

8. Peraturan Menteri Pendayagunaan Aparatur Negara dan Reformasi Birokrasi Nomor 29 Tahun 2010 tentang Pedoman Penyusunan Penetapan Kinerja dan Pelaporan Akuntabilitas Kinerja Instansi Pemerintah;

9. Peraturan Menteri Pendidikan Nasional Republik Indonesia nomor 18 tahun 2011 tentang Koordinasi dan Pengendalian Program di Lingkungan Kementerian Pendidikan Nasional Tahun Anggaran 2011. 


\section{Visi Misi dan Tujuan}

\section{1) Visi}

"Mewujudkan UPT. Perpustakaan Unram sebagai Pusat layanan informasi ilmiah, pengembangan Pendidikan, pengajaran, penelitian dan pengabdian kepada masyarakat yang bermutu, bertatakelola baik dan berdaya saing global berbasis teknologi informasi".

\section{2) Misi}

1. Menghimpun koleksi bahan pustaka yang bermutu sesuai standar nasional dan internasional berbasis teknologi informasi dalam rangka mengahsilkan sumber daya manusia yang berkualitas dan berwawasan luas.

2. Melaksanakankegiatan pembinaan dan pengembangan perpustakaan dan koleksi bahan pustaka sesuai standar nasional dan internasional untuk menghasilkan sumber informasi yang relevan dan akurat dalam menunjang pendidikan, pembelajaran, penelitian dan pengabdian kepada masyarakat yang bermutu dan berdaya siang global.

3. Melaksanakankegiatan pengolahan bahan pustaka koleksi dan informasi dalam rangka peningkatan input dan output pendidikan, pengajaran, penelitian dan pengabdian kepada masyarakat yang berkarakter dan berdaya saing global

4. Melaksanakan kegiatan layanan perpustakaan berbasis teknologi informasi

5. Membangun jaringan kerjasama perpustakaan yang luas dengan berbagai pihak, instansi pemerintah dan swasta, di dalam dan luar negeri, dalam rangka pelaksanaan fungsi perpustakaan yang berstandar nasional dan internasional yang berstandar nasional dan internasional

6. Melaksanakan kegiatan pembinaan dan pengembangan pustakawan dalam rangka peningkatan kompetensi yang berstandar nasional dan internasional

7. Melaksanakan tata kelola aset, keuangan dan administrasi yang baik, efisien, efektif, transparan dan dalam rangka untuk mendukung pelaksanaan perpustakaan perguruan tinggi bermutu.

\section{3) Tujuan}

1. Tersedianya Informasi / bahan pustaka baik tercetak maupun elektronik yang bermutu dan .diminati oleh pemustaka / Civitas akademika

2. Terselenggara kegiatan pengolahan informasi / bahan pustaka dengan cepat dan tepat sesuai standar pengolahan bahan pustaka.

3. Terlaksananya kegiatan pelayanan dan pendayagunaan informasi / bahan pustaka kepada seluruh civitas akademika Universitas Mataram dengan memperhatikan aspek kepuasan pemustaka.

4. Terpeliharanya koleksi / bahan pustaka tercetak dan elektronik sehingga dapat dimanfaatkan secara kontinu.

5. Tercapainya sistem penyelenggaraan perpustakaan berbasis teknologi in formasi dengan didukung oleh sumber daya pustakawan yang berkualitas dan memiliki kompetensi.

6. Terlaksananyakegiatan

administrasi tata usaha UPT. Perpustakaan Universitas mataram sebagai salah satu faktor pendukung kelancaran kerja perpustakaan dalam memberikan layanan informasi. 


\section{Hasil dan Pembahasan}

a. enerapan Aplikasi SLIMS Akasia Dalam Pelayanan Informasi Pemustaka di UPT Perpustakaan Universitas Mataram

Dengan melakakun serangkaian pengumpulan data menggunakan metode Observasi, Dokumentasi Dan Metode Wawancara terhadap Narasumber yang dipercaya dan sudah berpengalaman dibidang pelayanan informasi pemustaka yaitu: Pak Muslimin, S.Sos.,MM. Selaku kepala Perpustakaan Universitas Mataram.

Penerapan Aplikasi SLIMS Akasia Dalam Pelayanan Informasi Pemustaka di UPT Perpustakaan Universitas Mataram memiliki ruang tersendiri dan pelayanan informasi sudah menggunakan system automasi senayan liberary manegement sistem (SLIMS) Akasia. Aplikasi SLIMS Akasia di UPT Perpustakaan Universitas Mataram sangat membantu kelancara pelaksanaan tugas khusunya pelayanan informasi bagi civitas akademika Universitas Mataram. Baik layanan sirkulasi, akses online publik acces katalog (OPAC) dan hal ini sangat positif untuk mempercepat perkembangan Perpustakaan khususnya digital library.

\section{Gambar : 1.1}

Tampilan Aplikasi Slims Akasia di UPT Perpustakan Unram

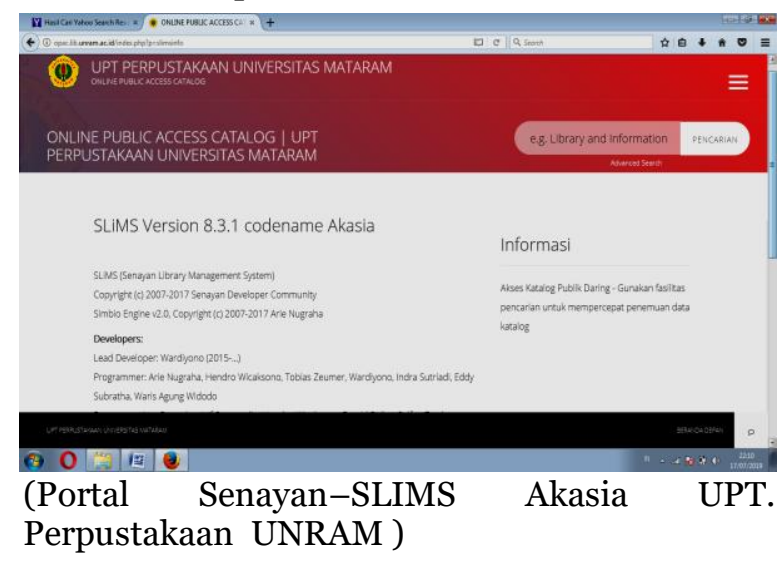

Print screen diatas merupakan salah satu bentuk tampilan muka dari aplikasi SLIMS Akasia yang diterapkan di UPT Perpustakaan Universitas Mataram. Aplikasi ini sangat mudah di gunakan untuk kegiatan pelayanan, pengolahan, pengadaan, serta akses informasi online untuk segenap pemustaka. Dalam perkembangan selanjutnya SLIMS ini senantiasa pengalami perubahan dan penyempurnaan, dengan menambah fitur-fitur terbaru untuk semakin baiknya proses pelayanan dan administrasi serta sistem informasi Perpustakaan. SLIMS merupakan sebuah jawaban akan kebutuhan portal aplikasi online untuk Perpustakaan.

Alasan Perpustakaan UNRAM memilih SLIMS Akasia karena sangat cocok dengan manajemen informasi perpustakaan apalagi di era globalisasi informasi dimana semua akses informasi harus dilaksanakan secara online. Sehingga kehadiran aplikasi ini sangat mendukung percepatan perkembangan perpustakaan.

Perbendaan Aplikasi SLIMS Akasia dan sebelumnya, SLIMS Akasia, dengan fitur-fitur yang lengkap dan dengan tampilan yang lebih menarik. Tapi pada intinya tidak ada perbedaan yang terlalu mencolok antar SLIMS Akasia dengan SLIMS sebelumnya hanya penambahan fitur-fitur seperti: live chat. untuk memudahkan operasional.

\section{b. Sistem Jaringan SLIMS Akasia di UPT Perpustakaan Universitas Mataram}

Sistem Jaringan SLIMS Akasia di UPT Perpustakaan Universitas Mataram adalah memakai sistem jaringan online karena memang di sanasudah digitalisasi dari pengadaan sampai pelayanan informasi pada pemustaka.

Sistem jaringan SLIMS Akasia berbasis online, sehingga SLIMS Akasia ini sama dengan SLIMS sebelunya, mengepurnakan fitur-fitur SLIMS yang sebelumnya karena sifat dapat 
menghemat waktu penusularan informasi pemustaka sehingga bisa diakses di mana saja oleh pemustaka pada umunya.

Dalam Penerapan aplikasi SLIMS Akasia dalam pelayanan informasi pemustaka tersebut, UPT Perpustakaan Universitas Mataram menggunakan 3 buah Komputer. 1 buah komputer digunakan sebagai komputer server SLIMS Akasia dan 1 komputer di gunakan PC Client, 1 buah komputer dijadikan OPAC untuk penelusuran informasi pemustaka.

Aplikasi SLIMS Akasia sangat cocok dengan manajemen informasi Perpustakaan apalagi di era globalisasi informasi dimana semua akses informasi dilaksanakan secara online. Sehingga kehadiran aplikasi ini sangat memdukung percepatan perkembangan Perpustakaan. Kunci dari layanan Perpustakaan adalah tercapainya kepuasan pemustaka (user satisfaction) sehingga untuk mewujudkan hal tersebut butuh sistem pengelolahan Perpustakaan yang terpadu dan terintegrasi untuk efektif dan efesien kinerja Perpustakaan.

Kegiatan pelayanan Perpustakaan merupakan inti dari seluruh kegiatan Perpustakaan. Keberhasilan sebuah lembaga perpustkaan sangat di tentukan oleh kualitas Pelayanan Perpustakaan. Pelayanan merupakan suatu kegiatan penyedian bahan pustaka secara tepat, akurat dan cepat dalam memenuhi kebutuhan informasi bagi pemustaka. tujuan Perpustakaan memberikan layanan kepada masyarakat agar bahan pustaka yang telah dihimpun dan diolah sebaik-baiknya dapat dimanfaatkan oleh pemustaka. Layanan Perpustakaanberfungsi mendekatkan pembaca dengan bahanpustaka yang dibutuhkan dan diminatinya.

\section{c. Layanan Sirkulasi Menggunakan SLIMS} Akasia di UPT Perpustakaan UNRAM :

1) Layanan Sirkulasi adalah kegiatan kerja yang berupa pemberian bantuan kepada pemustaka di perpustakaan dalam proses peminjaman dan pengembalian bahan pustaka.

Salah satu kegiatan utama atau jasa utama perpustakaan adalah peminjaman bahan pustaka dan pengembalian bahan pustaka. Kegiatan peminjaman ini sering dikenal dengan nama sirkulasi artinya peminjaman. Meja sirkulasi, seringkali di anggap ujung tombak jasa perpustakaan karena bagian inilah yang pertama kali berhubungan dengan pemustaka atau seseorang yang memanfaatkan perpustakaan serta paling sering di gunakan seseorang, karenannya unjuk kerja staf sirkulasi dapat berpengaruh terhadap citra perpustakaan.

Kegiatan layanan sirkulasi ini sering berhubungan dengan pemustaka sehingga dapat dikatakan sebagai ujung tombak dari perpustakaan. Ada beberapa kegiatan yang dilakukan dalam layanan sirkulasi.

kegiatan layanan sirkulasi meliputi antara lain:

a) Kegiatan yang berhubungan dengan peminjaman koleksi

b) Pengembalian koleksi

c) Pemungutan denda

d) Perpanjang kartu anggota

Gambar: 1.2

Tampilan layanan sirkulasi di UPT Perpustakaan UNRAM

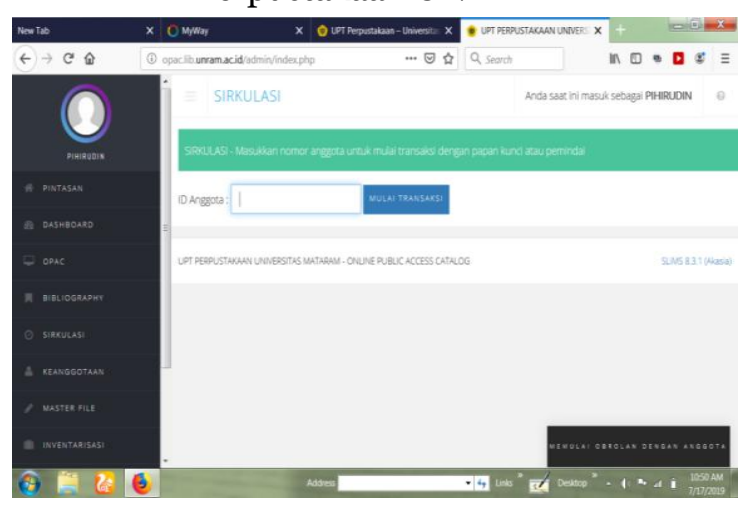

Tampilan gambar layanan sirkulasi SLIMS Akasia di UPT Perpustakaan Unram yang digunakan untuk kegitatan sirkulasi 
seperti peminjaman bahan pustaka, pengembalian bahan pustaka, dan memperpanjang masa pinjam bahan pustaka. Tampilan sirkulasi terdiri dari pengisian id anggota yang di oleh pustakawan apabila pemustaka ingin melakukan traksaksi peminjam dan pengembalian bahan pustaka.

2) Bibliografiadalah publikasi yang memuat daftar dokumen baik yang "diterbitkan" dalam bentuk buku maupun artikel majalah atau bentuk kepustakaan lain yang berhubungan dengan bidang, ilmu pengetahuan atau hasil karya seseorang.

\section{Gambar: 1.3}

Tampilan Bibliografi UPT Perpustakaan UNRAM

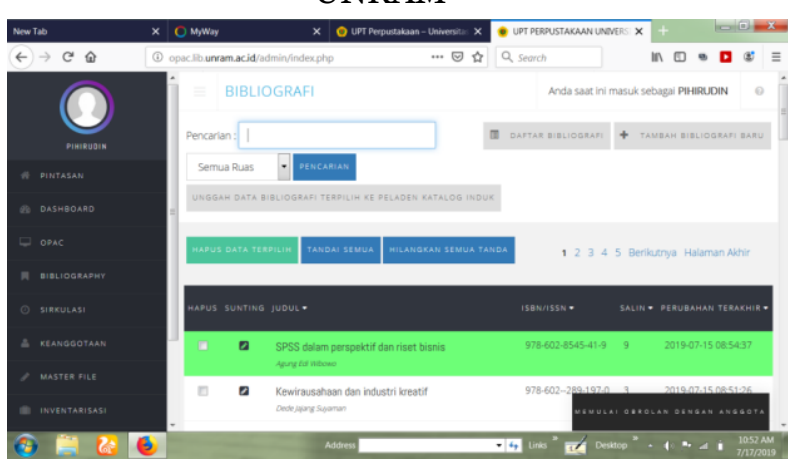

TampilanBibliografiberfungsi untuk mengetahui bagian dari bahan pustaka secara rinci. bibliografi berisi pencarian, daftar bibliografi, tambah bibliografi. pencarian digunakan untuk mencari bahan pustaka yang datanya ada di daftar bibliografi. daftar bibliografi berisi daftar bahan pustaka yang datanya telah di input ke dalam bibliografi. Apabila bahan pustaka yang ada di perpustakaan datanya belum di input atau tidak terdapat di daftar bibliografi, maka bahan pustaka tersebut harus didaftarkan terlebih dahulu melalui ikon sub menu tambahkan bibliografi.

3) Online Public Acces Catalog (OPAC) merupakan suatu alat bantuan penelusuran informasi atau via katalog komputer yang berisikan cantuman bibliografi dan dapat diakses secara umum untuk menemukan koleksi di suatu Perpustakaan

Gambar: 1.4 Tampilan OPACSLIMS Akasia UPT Perpustakaan UNRAM

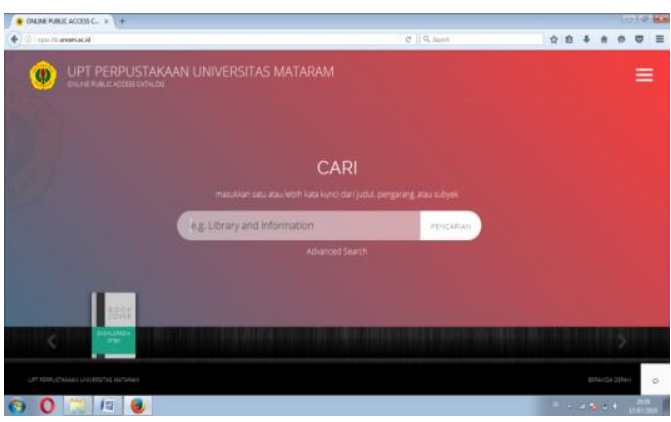

Tampilan OPAC SLIMS Akasia menjadi lebih berbeda. OPAC SLIMS Akasia menjadi terlihat sederhana namun tetap memiliki kesan elegan. Banyak perubahan yang dihasilkan pada tampilan OPAC SLIMS Akasia yaitu antara lain penambahan logo menu. Menu yang disediakan.

\section{Gambar: 1.4.2}

Tampilan menu Library News,

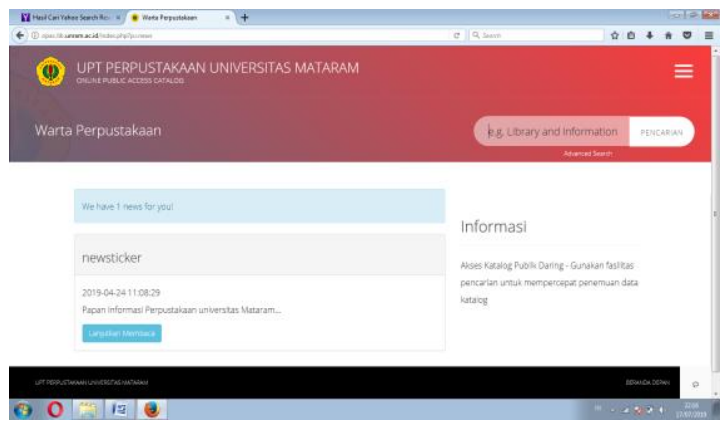

Tampilan library newsditujukan sebagai halaman untuk penyampaian berita kegiatan yang dilakukan oleh perpustakaan. Halaman ini dapat digunakan untuk content management system (CMS) secara sederhana. Dengan fitur ini, perpustakaan dapat menyampaikan liputan tentang kegiatan perpustakaan. 


\section{Gambar: 1.4.3}

Tampilan menuLibrary Information,

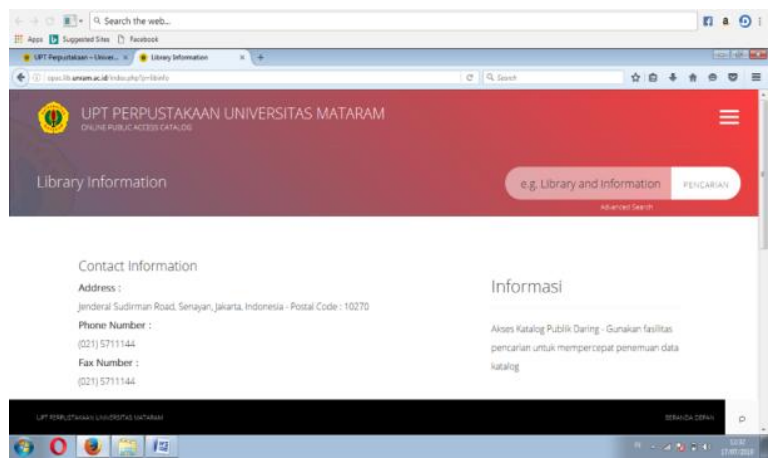

Tampilan library information menyediakan informasi singkat tentang perpustakaan. Mulai dari alamat, nomor telepon, hingga jenis koleksi yang disediakan oleh perpustakaan tersebut. Selain itu dapat diisi tentang apapun yang menggambarkan perpustakaan tersebut.

Gambar: 1.4.4

Tampilan menulibrary Location,

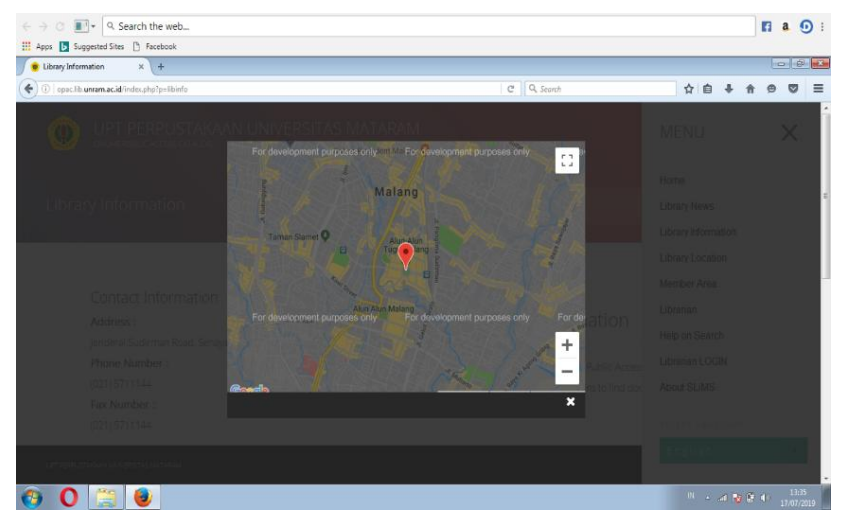

Tampilan menu library location perpustakaan dapat menunjukkan lokasi perpustakaannya menggunakan google maps dengan memasukkan koordinat lokasi perpustakaan.

\section{Gambar: 1.4.5}

Tampilan menuMember Area,

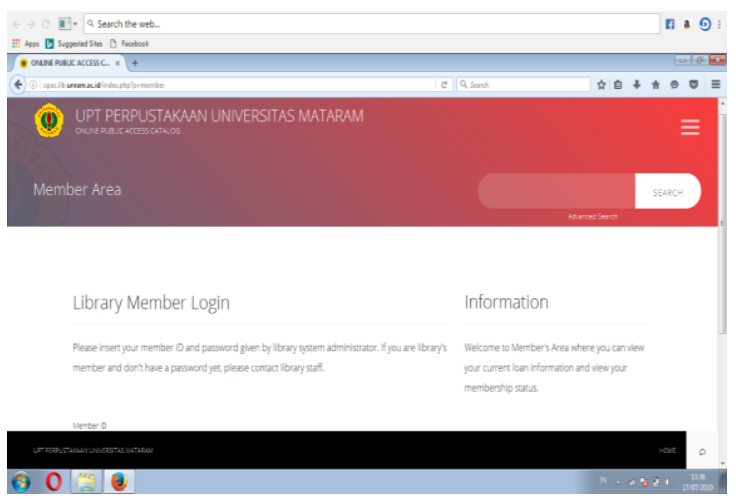

Tampilan menu member area memberikan kemudahan bagi pemustaka untuk dapat memantau peminjaman yang masih aktif atau sejarah peminjaman. Pada menu ini pemustaka juga dapat melakukan booking (pemesanan) bahan pustaka

Gambar: 1.4.6

TampilanmenuLibrarian,

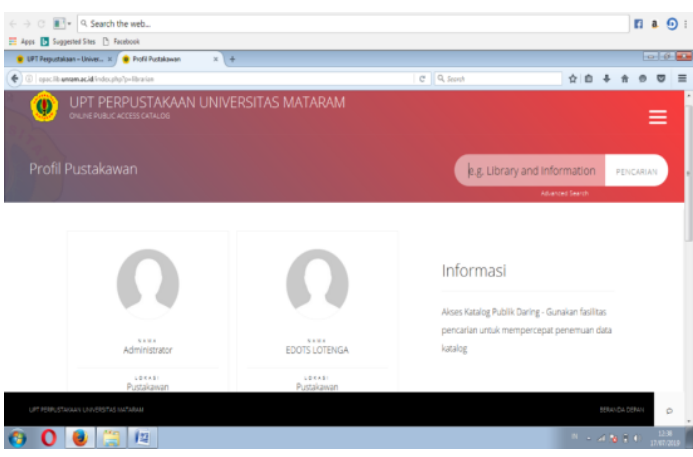

Tampilan menu librarian menyajikan informasi profil diri pustakawan

Gambar: 1.4.7

Tampilan menu Help on Search,

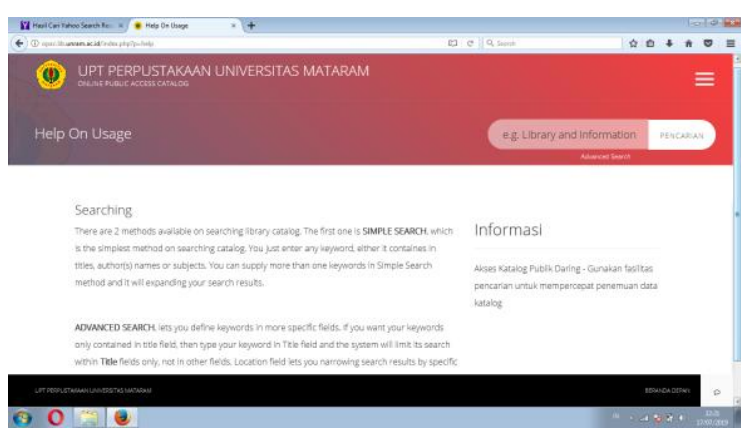

Tampilan menu ini memberikan penjelasan secara sederhana tentang bagaimana melakukan pencarian informasi. 
Gambar: 1.4.8

TampilanmenuLibrarian Login,

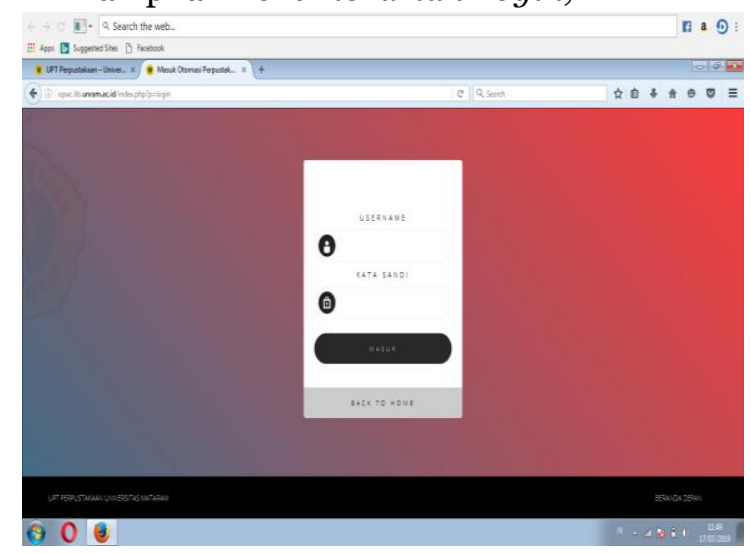

Tampilan menu librarian login digunakan untuk mangakses backend SLIMS. Menu ini ditujukan bagi pengelola perpustakaan yang memiliki akses.

Gambar: 1.4.9

Tampilan Menu About SLiMS,
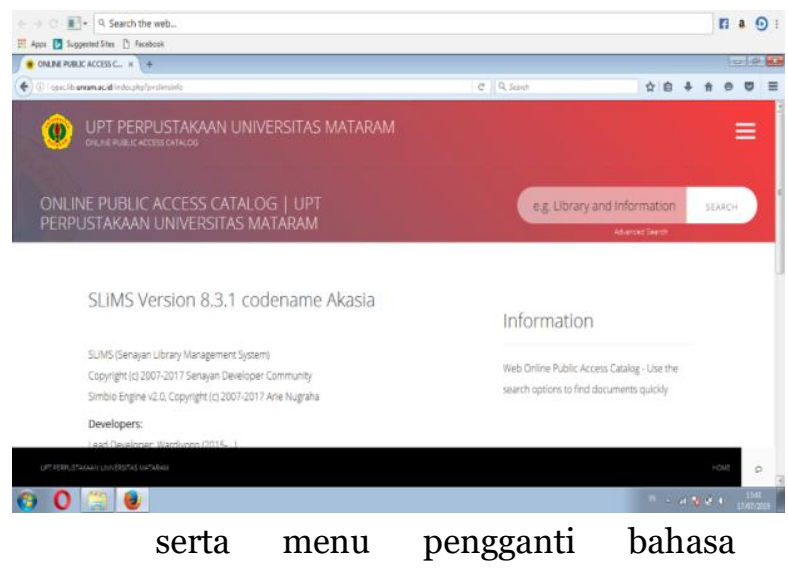

antarmuka. Kolom pencarian menjadi lebih simpel karena hanya menyediakan satu kolom saja namun tidak mengurangi kualitas hasil pencarian. Penambahan fitur pada OPAC SLIMS Akasia adalah fitur live chat. Kemudian penempatan media sosial juga dirubah menjadi di bagian footer.

1. Keanggotaan merupakan tanda bukti bahwa pemustaka yang menggunakan Perpustakaan sudah mendaftarkan dirinya sebagai anggota perpustakaan. Keanggotaan ini meneunjukkan bahwa pemegangnya mempunyai hak untuk fasilitas Perpustakaan, membaca, dan meminjam bahan pustaka yang ada di Perpustakaa.

Gambar: 1.5

Tampilan Keanggotaan SLIMS Akasia UPT Perpustakaan Unram

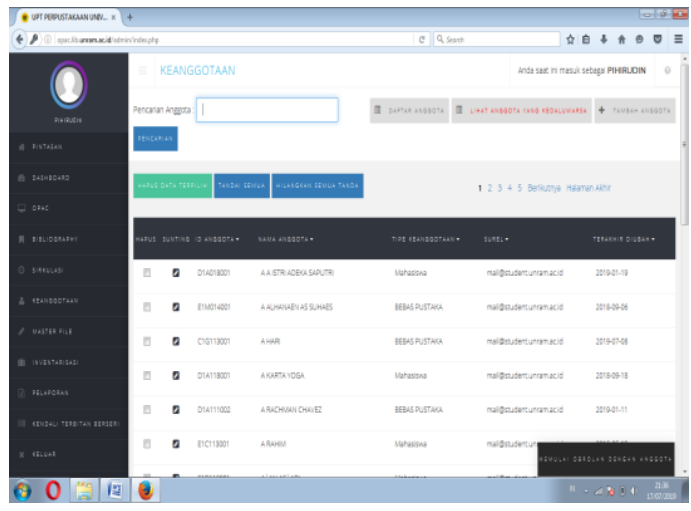

Tampilan gambar keanggotaan SLiMS Akasia di Unram yang digunakan untuk keanggotaan perpustakaan seperti membuat kartu anggota perpustakaan dan memperpanjang masa keanggotaan perpustakaan. Pemustaka yang ingin menjadi anggota perpustakaanharus mendaftar keanggotaan kepada pustakawan. sedangkan bagi pemustaka yang ingin memperpanjang masa keanggotaan perpustakaan maka harus konfirmasi kepada pustakawan supaya masa keanggotaan tersebut dapat diperpanjang oleh pustakawan.

Manfaat bagi Perpustakaan ada Penarapan Aplikasi SLIMSAkasis Dalam Pelayanan Informasi Pemustaka di UPT Perpustakaan Universitas Mataram:

1. Kerja menjadi lebih mudah

2. Informasi yang di kelolah menjadi sistematis

3. Tersedia pusat data informasi bibliografi untuk pemustaka

4. Terbagunnya sistem informasi online dan terintegrasi

5. Memudahkan kerjasama inter library loan dengan ketersedian data katalog online 
Kendala apa saja dalam Penerapan Aplikasi Senayan Library Management System (SLIMS) Akasia Dalam Pelayanan Informasi Pemustaka di UPT Perpustakaan Universitas Mataram

Setiap kegiatan pastinya tidak luput dari kendala ataupun hambatan yang mudah diatasi maupun yang sulit untuk diatasi. Namun dalam penelitian ini penulis menemukan beberapa kendala dalam penerapan aplikasi SLIMS Akasia dalam pelayanan informasi pemustaka di UPT Perpustakaan Universitas Mataramyaitu sebagai berikut:

1. Listrik

Seringmati lampu disaat server sedangaktif, sehinggakegiatanpelayanan informasi pemustaka menjadi terhambat dan tidak bisa di lakukan, karna padasaat listrik mati internetnya sudah tidak bisa digunakan dalam proses pelayanan informasi pemustaka.

2. Kurang Keterampilan dan pemahaman pustakawan. Keterampilan dan pemahaman pustakawan masih perluh ditingkatkan dalam mengoperasikan sistem SLIMS Akasia,

3. Kurang pengetahuan pemustaka dalam memanfaatkan online public access catalog (OPAC). Kurang sosialisasi tentang user education, pengetahuan dalam memanfaatkan OPAC sehingga pemustaka kebingunan mencari informasi tersebut.

4. Pemustaka kesulitan mencari baha koleksi yang dibutuhkan, seperti kesulitan dalam mencari bahan koleksi di (OPAC), karena meraka tidak taucara mengunakan OPAC.

5. Penyalahgunakan kartu anggota perpustakaan. Contohnya seperti banyak mahasiswa yang menggunakan kartu anggota temannya. Sehingga teman yang punya tidak tau bawasan kartu di pakai oleh teman.

Solusi-Solusi yang diperlukan dalam mengatasi kendala-kendala yang dihadapi dalam Penerapan Aplikasa SLIMS Akasia Dalama Pelayana Informasi di UPT Perpustakaan Universitas Mataram, Kendalakendala yang dihadapi oleh UPT Perpustakaan Universitas Mataram dalam penerapan aplikasi SLIMS Akasia dalam pelayanan informasi pemustaka tentunya harus segera diambil solusi yang tepat agar tidak menjadi batu sandungan yang nantinya akan menghabat dinamika perpustakaan.

1) Mengatasi Masalah yang timbul di atas, dalam penarapan aplikasi SLIMS Akasia dalam pelayanan informasi pemustaka adalah menprogramkan untuk pengadaan genset sebagai langkah antisipasi bila terjadi mati lampu, angar pelayanan informasi pemustaka tidak terhambat dan pemustaka yang berkunjung di perpustakaan tidak merasa kecewa.

2) Mengadakan worshop dan pelatihan untuk meningkatkan kualitas, keterampilan(Skill) pustakawan agar lebih handal mengoperasikan SLIMS Akasia dalam pelayanan informasi pemustka di UPT Perpustakaan Universitas Mataram.Dengan mengadakan worshop pustakawan yang mini pengetahuan tentang Penerapan Aplikasi SLIMS Akasia Dalam Pelayanan Informasi Pemustaka di UPT Perpustakaan Universitas Mataram. Oleh karena itu sangat sangat penting mengadakan worshop untuk menambah pengetahuan tentang SLIMS Akasia dalam pelayanan informasi pemustaka

3) Mengadakan literasi informasi terhadap pemustaka yang kurang pengetahuan tentang penelusuran informasi atau memanfaatkan OPAC tomohiet onhinore nomustolyo roner holum tou

Kegiatan layanan literasi informasi masih jarang dilakukan oleh perpustakaan maupun pustakawan, pada hal ini sangat penting karena mempengaruhi pemanfaatan koleksi maupun sumber informasi di perpustakaan. Dengan diadakan atau diselenggarakan Literasi Informasi 
kepada pemustaka khususnya pemustaka baru, maka pemanfaatan perpustakan akan meningkat dan akan memberikan citra terhadap perpustakaan. Disamping itu ada sebuah tantangan dan tuntutan yang besar bagi perpustakaan dalam mengembangkan layanan bagi pemustaka. Tantangan ini seiring dengan kemajuan teknologi yang berkembang sedemikian pesatnya. Dengan kemajuan teknologi informasi pemustaka telah dimanjakan dengan kemudahan, keleluasaan dan kecepatan akses terhadap informasi yang dibutuhkan. Di dalam perpustakaan sendiri, kita telah disibukkan dengan berbagai kegiatan dan pengelolaan yang berkaitan dengan pekerjaan rutin, baik dalam pengolahan koleksi, pengelolaan database, multimedia, data jaringan, pelayanan koleksi baik dalam bentuk buku hadcopy maupun dalam bentuk digital serta pengembangan web perpustakaan dan penyajian informasi-informasi yang dibutuhkan oleh pemustaka.Literasi informasi bagi pemustaka sangat diperlukan, karena hal ini sangat membantu bagi pemustaka untuk memperoleh sumber-sumber informasi yang mereka butuhkan, sehingga pustakawan memiliki peran strategis dalam menginformasikan pustakawan harus membantu pemustaka yang memcarikan informasi yang dibutuhkan oleh pemustaka. Sehingga pemustaka yang kesulitan mencari informasi tersebut tidak merasakan kesulitan dalam mencari informasi Contohnya informasi seperti saya ingin mencari lahir teori relativitas dari Einstein? Sehingga pemustaka yang membutuhkan informasi aka merasa senang. Sebelum melakukan kegiatan pelayana peminjaman dan pengembalian bahan pustaka, Pustakawaan harus cek kartu anggota atau cocokan fotonya yang kartu anggota dengan pemustaka menggunakan kartu anggotaapakah sama atau tidak. Sehingga menjaga terjadinya penyalagunaan kartu anggota oleh pemustaka.

\section{H. KESIMPULAN DAN SARAN}

\section{Kesimpulan}

Analisis Dari Pembahasan Maka Penulis Dapat Mengambil Kesimpulan Sebagai Berikut:

a. Penerapan Aplikasi SLIMSAkasia di UPT Perpustakaan UNRAM sangat cocok dengan manajemen informasi Perpustakaan. Karena memiliki fiturfitur yang lengkap dengan tampilan muka yang lebih menarik. Peranrapan SLIMS Akasia dilakukan dalam beberapa pelayanan yaitu: layanan sirkulasi terdiri dari peminjaman bahan pustaka, pengembalian bahan pustaka, Perpanjangan masa pinjam bahan pustaka, pembuatan kartu anggota Perpustakaan, perpanjang masa keanggotaan perpustakaan, penentuan denda, OPAC, bibliografi dan keanggotaan.

b. Kendala yang di hadapi pustakawan dalam melakukan penerapan Aplikasi SLIMS Akasia dalam pelayanan informasi pemustaka di UPT Perpustakaan Universitas Mataramyaitu: sering mati lampu saat server sedang aktif dan keterampilan dan pemahaman pustakawan masih perlu di tingkatkan dalam mengoperasikan. kurangnya keterampilan dan pemahaman pustakawan, pemustaka kesulitan mencari bahan koleksi yang dibutuhkan, seperti kesulitan dalam memcari bahan pustaka di OPAC, karena mereka tidak 
tau cara mengunakan OPAC. penyalahgunakan kartu anggota perpustakaan

\section{Saran}

Dari hasil kesimpulan masalah di atas terkait implementasi kebijakan penyiangan koleksi di UPT Perpustakaan Universitas Muhammadiyah Mataram, peneliti memberi saran atau masukan sebagai berikut:

a. karna sering mati lampu, menganggu pelayana informas hendaknya perpustakaan menyediakan jenset tersendiri dan hendaknya setiap melakukan pengimputan data untuk sealalu disimpan sebelum lanjut ke inputan data yang lain.

b. Pustakawan harus meningkatkan pengetahuan terhadap SLIMS Akasia, perlu diadakan pelatihan baik yang sifatnya internal, lokal maupun nasional.

c.Perpustakaan perlu mengadakan literasi terhadap pemustaka yang kurang pengetahuan tentang penelusuran informasi atau memanfaatkan OPAC tersebut sehingga pemustaka yang belum tau tentang penelusuran informasi.

d. Pustakawan harus membantu pemustaka yang mencari informasi yang di butuhkan pemustaka.

e.Oleh karena itu sering terjadinya penyalagunaan kartu anggota oleh pemustaka. Pustakawan harus cek kartu anggota atau cocokan dengan pemustaka menggunaka kartu anggota apakah sama atau tidak fotonya.

\section{DAFTAR PUSTAKA}

Harrod, 1987. Definisi pustakawan pdf. Di akses pada tgl 20 juni 2019: jam 10:00 wita

Indonesia, Pendidikan Nasional Republik, Tim Penyusun. Perpustakaan Perguruan Tinggi: Buku Pedoman, edisi ketiga. Jakarta :

Direktorat Jenderal Pendidikan Tinggi. 2004.

Keputasan menteri pendidikan dan kebudayaan. No.0103/0/1981.

Lasa HS. 1994. Jenis-jenis Pelayanan Informasi Perpustakaan. Yogyakarta : UGM Press.

Lubis, 2008, kinerja pustakawan pdf di akses pada tanggal 20 juni 2019 , jam 10:00 wita

Mulyadin .2017. pengelolahan otomasi perpustakaan berbasis senaya libarary management system (slims)

Modul. 2018Pemanfataan Portal Online Public Acces Cataloque Berbasis "Slims Akasia" Upt. Perpustakaan Universitas Mataram

Menpan No. 132/Kep/M.Pan/12/2002.

Noerhayati. 1987, pengertian perpustakaan perguruan tinggi pdf, di akses pada tgl 20 mei 2019: jam 10:00 wita

Rahman dan zen, 2006, kinerja pustakawan pdf di akses pada tanggal 20 juni 2019 , jam 10:00 wita

Sulistyo-Basuki. 1993. Pengantar Ilmu Perpustakaan. Jakarta: Gramedia Pustaka Utama.

Sugiyono. 2012. Metode Penelitian Kuantitatif Kualitatif dan $R \& D$. Bandung: Alfabeta

Undang-Undang Republik Indonesia Nomor 43 Tahun 2007 Tentang Perpustakaan

Wirawan, 2009. kinerja pustakawan pdf di akses pada tanggal 20 juni 2019 , jam 10:00 wita 
Wiji suwarno. 2001. Definisi perpustakaan pdf. Di akses pada tgl 12 mei 2019: jam 10:00 wita.

http://eprint.uny.ac.id/7708/bab\%202\%20\%200610121046.pdf. senyan library manajemen system versi_19 di akses pada tgl 20 juni 2019, jam 10:00 wita

Pak Muslimin, wawancara tentang penerapan aplikasi slims akasia dalam pelayana informasi pemustak pada tgl 20 juni 2019. 